\title{
Periosteal Bone Apposition in Chondroblastoma
}

\author{
E. Braunstein, M.D. ${ }^{1}$, W. Martel, M.D. ${ }^{1}$, and L. Weatherbee, M.D. ${ }^{2}$ \\ ${ }^{1}$ Department of Radiology, and ${ }^{2}$ Department of Pathology, University of Michigan, Ann Arbor, Michigan, USA
}

\begin{abstract}
Periosteal bone apposition in chondroblastoma of long bones is more frequent than generally recognized. This should not cause confusion in differential diagnosis. The finding does not seem to have prognostic significance.
\end{abstract}

Key words: Periosteal bone apposition - Chondroblastoma.

Although periosteal bone apposition is a recognized manifestation of chondroblastoma $[1,4,6,9]$, this

Address reprint requests to: E. Braunstein, M.D., Department of Radiology, University of Michigan Medical Center, Ann Arbor, MI 48109, USA has been thought to be relatively uncommon. However, in our experience this is more frequent than has been appreciated. We reviewed the medical records, roentgenograms, and pathologic material in ten patients with confirmed chondroblastoma to determine the frequency and character of such bone apposition and whether it had prognostic significance.

\section{Results}

Clinical and roentgen features with respect to bone apposition are summarized in Table 1. The patients' ages varied from 10 to 32 years. All but one were males. The follow-up period varied from one to 10 years. None had recurrence after surgery.

Table 1.

\begin{tabular}{|c|c|c|c|c|}
\hline $\begin{array}{l}\text { Case } \\
\text { No. }\end{array}$ & Location & $\begin{array}{l}\text { Periosteal }{ }^{a} \\
\text { new bone }\end{array}$ & $\begin{array}{l}\text { Clinical } \\
\text { findings }\end{array}$ & Follow-up \\
\hline 1 & $\begin{array}{l}\text { Proximal femoral } \\
\text { epiphysis }\end{array}$ & ++ & $\begin{array}{l}\text { Female, age } 15 \text { years, } \\
\text { groin pain and limp }\end{array}$ & No recurrence after 2 years \\
\hline 2 & $\begin{array}{l}\text { Distal tibial epiphysis } \\
\text { (fused) }\end{array}$ & ++ & $\begin{array}{l}\text { Male, age } 32 \text { years, } \\
\text { ankle pain and tenderness }\end{array}$ & No recurrence after 4 years \\
\hline 3 & $\begin{array}{l}\text { Proximal femoral } \\
\text { metaphysis }\end{array}$ & ++ & $\begin{array}{l}\text { Male, age } 18 \text { years } \\
\text { hip and knee pain, limp }\end{array}$ & No recurrence after 2 years \\
\hline 4 & $\begin{array}{l}\text { Proximal femoral } \\
\text { epiphysis }\end{array}$ & + & $\begin{array}{l}\text { Male, age } 19 \text { years, } \\
\text { hip pain and limp }\end{array}$ & No recurrence after 3 years \\
\hline 5 & $\begin{array}{l}\text { Proximal tibial } \\
\text { epiphysis }\end{array}$ & +++ & $\begin{array}{l}\text { Male, age } 16 \text { years, } \\
\text { trauma to knee, } \\
\text { progressive pain and limp }\end{array}$ & No recurrence after 10 years \\
\hline 6 & $\begin{array}{l}\text { Proximal femoral } \\
\text { epiphysis }\end{array}$ & + & $\begin{array}{l}\text { Male, age } 11 \text { years, } \\
\text { knee pain and limp }\end{array}$ & No recurrence after 10 years \\
\hline 7 & $\begin{array}{l}\text { Proximal tibial } \\
\text { epiphysis }\end{array}$ & + & $\begin{array}{l}\text { Male, age } 16 \text { years, } \\
\text { pain and swelling } \\
\text { post meniscectomy }\end{array}$ & No recurrence after 3 years \\
\hline 8 & Talus & 0 & $\begin{array}{l}\text { Male, age } 16 \text { years, } \\
\text { right ankle pain }\end{array}$ & No recurrence after 4 years \\
\hline 9 & $\begin{array}{l}\text { Humeral head epiphysis } \\
\text { (fused) }\end{array}$ & +++ & $\begin{array}{l}\text { Male, age } 24 \text { years, } \\
\text { shoulder pain }\end{array}$ & No recurrence after 1 year \\
\hline 10 & $\begin{array}{l}\text { Humeral head epiphysis } \\
\text { (fused) }\end{array}$ & + & $\begin{array}{l}\text { Male, age } 13 \text { years, } \\
\text { shoulder pain }\end{array}$ & No recurrence after 1 year \\
\hline
\end{tabular}

a + Slight, +++ moderate 


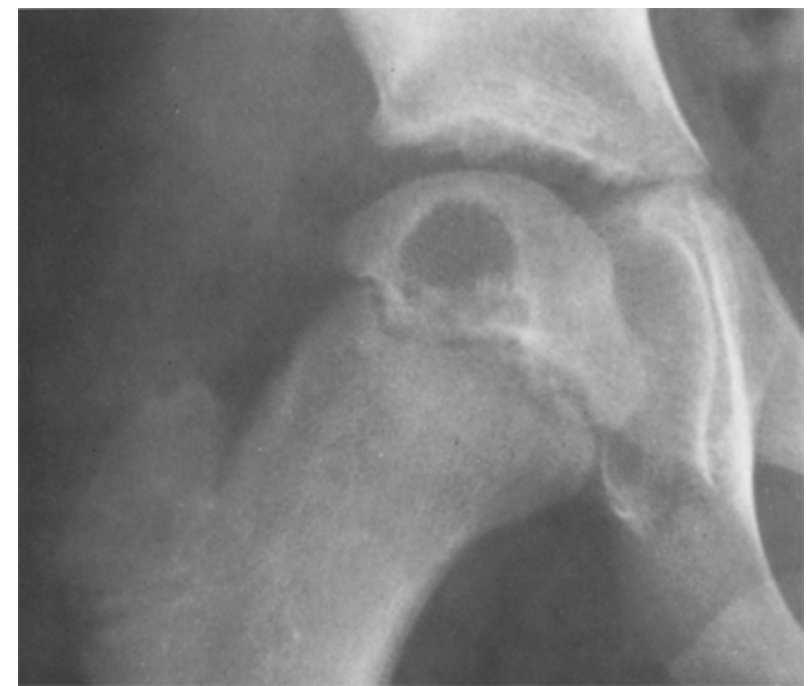

Fig. 1. Case No. 6. Chondroblastoma of proximal femoral epiphysis with minimal periosteal bone apposition along medial aspect of femur distal to lesion cally occurred in the metaphysis slightly removed from the lucent component of the lesion (Figs. 1 and 2). In the metaphyseal lesion, the bone apposition developed near the distal pole of the lesion in the metadiaphyseal region. The bone apposition was present in all three cases in which the epiphysis had fused.

\section{Discussion}

Periosteal bone apposition is an important and characteristic finding in chondroblastoma of long bones. In a review of 130 chondroblastomas of long bones, this finding was present in 58 [5]. Periosteal new bone seems to occur regardless of the site of the lesion, or whether the epiphysis has fused.

The pathogenesis of this feature is unclear. Although periosteal bone apposition was observed on microscopic examination, its relation to the lesional
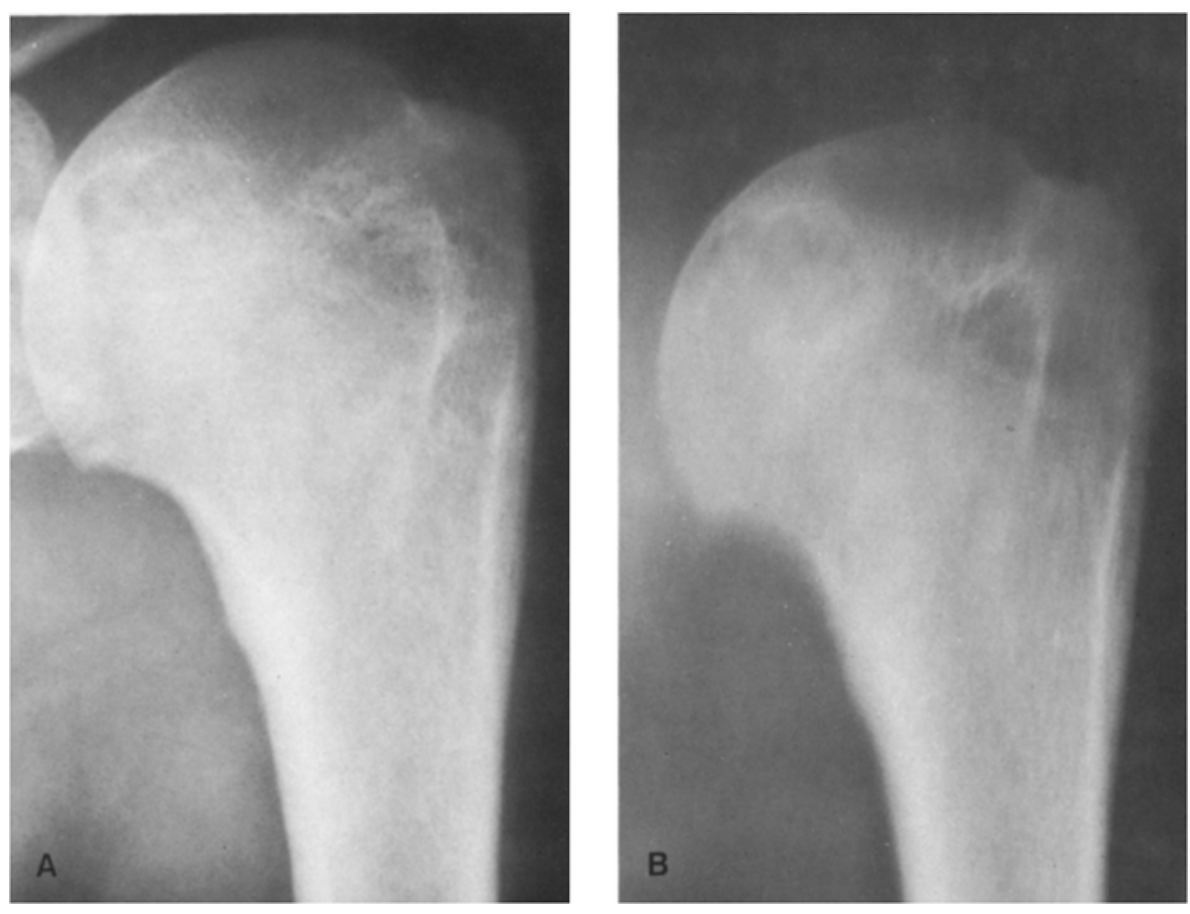

Fig. 2. Case No. 9.

A Chondroblastoma of humeral head with moderate periosteal reaction distal to lesion. B Tomogram showing smooth, laminated appearance of new bone
In eight of our cases the lesion involved the epiphysis of a long bone. The proximal femoral metaphysis [2] and talus were affected in two cases. Periosteal bone apposition was minimal to moderate and was associated with all lesions except the one in the talus. It was always linear and smooth, and was homogeneously calcified or laminated. It characteristi- tissue could not be appreciated because the surgical specimen was invariably received in fragments. It may be possible that reaction to mechanical stress due to weight-bearing plays a role, but it is significant that it occurs not only in the femur and tibia, but in the humerus, as well. Conceivably, a humeral factor could be responsible for producing such a reac- 
tion. It is not related to the aggressiveness of the lesion, inasmuch as there have been no recurrences in any of our cases.

In our experience, periosteal reaction is more common in chondroblastoma than previously thought [3, 7, 8]. Although the amount of bone apposition may be minimal, it is frequently present, and should not be the basis for confusion with other conditions. It is of interest that periosteal reaction also was present in the metaphyseal tumor (Case 3). The location of new bone, slightly removed from the site of the tumor, may be a differentiating feature from other lucent epiphyseal lesions, such as infections. In the latter, the periosteal response, if present, is characteristically adjacent to the lesion.

\section{References}

1. Alexander, C.: Case Report 5. Skeletal Radiol. 1, 63 (1976)

2. Aronsohn, R., Hart, W., Martel, W.: Metaphyseal chondroblastoma of bone. Am. J. Roentgenol. 127, 686 (1976)

3. Dahlin, D., Ivins, J.: Benign chondroblastoma. Cancer 30, 401 (1972)

4. Jaffe, H., Lichtenstein, L.: Benign chondroblastoma of bone: Reinterpretation of so-called calcifying or chondromatous giant cell tumor. Am. J. Pathol. 18, 969 (1942)

5. Johnson, L., Madewell, J.: Personal communication

6. Lodwick, G.: The bones and joints. Chicago: Yearbook Medical Publishers 1971

7. Mc Leod, R., Beabout, J.: The roentgenographic features of chondroblastoma. Am. J. Roentgenol. 118, 464 (1973)

8. Plum, G., Pugh, D. : Roentgenologic aspects of benign chondroblastoma of bone. Am. J. Roentgenol. 79, 584 (1958)

9. Sherman, R., Uzel, A.: Benign chondroblastoma of bone. Am. J. Roentgenol. 76, 1132 (1956) 